\title{
DEOXYRIBONUCLEIC ACID CONTENT IN DELAYED MOUSE BLASTOCYSTS
}

\author{
M. I. SHERMAN* AND P. W. BARLOW $\dagger$ \\ Department of Zoology, University of Oxford, and \\ Paediatric Research Unit, Guy's Hospital Medical School, London
}

(Received 8th September 1971, accepted 19th November 1971)

It has been demonstrated that mouse blastocysts in delay, either lactational or following ovariectomy, are metabolically quite inactive (see McLaren, 1972). Although cell division continues in the first few days following the onset of delay (McLaren, 1968), mitotic figures are not seen in blastocysts held in delay for several days (McLaren, 1968; see Table 1). Just as trophoblast outgrowth characteristic of the implantation event may be reproduced in the appropriate culture media (Mintz, 1964; Cole \& Paul, 1965), so too can delay of this event be achieved in vitro. Gwatkin (1966) has shown that omission of arginine and leucine from Eagle's medium can prevent trophoblast outgrowth from blastocysts for several days. Viability is apparently unaffected, as restoration of the missing amino acids to the medium after 7 days results in trophoblast outgrowth (Gwatkin, 1966); furthermore, two normal 10th day embryos were found $6 \frac{1}{2}$ days after transfer to pseudopregnant mothers of twelve blastocysts delayed in vitro for 4 days (C. F. Graham and M. I. Sherman, unpublished).

Because cell division is depressed in delayed blastocysts in vivo and in vitro, nuclear DNA contents were measured to determine the stage in the cell cycle at which blockage had occurred. Table 1 shows that at the time of measurement ( $7 \frac{1}{2}$ days post coitum (p.c.) for blastocysts maintained in delay in culture, $9 \frac{1}{2}$ days p.c. for blastocysts in ovariectomized hosts), mitotic figures were absent. Cultured blastocysts showed no increase in cell number (cf. Sample 2 with Sample 1, normal blastocysts obtained at noon on the 4th day of pregnancy), suggesting that introduction into the delay medium caused a relatively rapid cessation of cell division. On the other hand, some blastocysts in ovariectomy delay (Sample 3) showed substantial increases in cell number before cell division ceased. This has been previously reported by McLaren (1968) for blastocysts in lactational delay. The DNA contents of nuclei from normal and delayed blastocysts can be seen in the histograms in Text-fig. 1. The absorbance of Feulgen-stained euploid $2 \mathrm{C}$ and $4 \mathrm{C}$ nuclei (where $\mathrm{C}$ is the haploid amount of DNA) has been determined by measurements on adult liver nuclei (Text-fig. 1D). Text-figure 1A shows that the large majority of nuclei in ovariectomydelayed blastocysts contain less than 2.5 times the haploid amount of DNA. It is, thus, assumed that the block in the cell cycle is mainly in the Gl phase

* Present address: Department of Cell Biology, Roche Institute of Molecular Biology, Nutley, New Jersey 07110 , U.S.A.

$\dagger$ Present address: Unit of Developmental Botany, University of Cambridge, Huntingdon Road, Cambridge. 
TABLE 1

GELL NUMBERS OF NORMAL AND DEJAYED BLASTOCYSTS OF SWISS ALBINO (STRAIN PO) MICE

\begin{tabular}{c|c|c|c|c|c}
\hline $\begin{array}{c}\text { Sample } \\
\text { no. }\end{array}$ & $\begin{array}{c}\text { Age of } \\
\text { blastocyst } \\
\text { (days) }\end{array}$ & $\begin{array}{c}\text { No. of } \\
\text { blastocysts }\end{array}$ & $\begin{array}{c}\text { Average cell } \\
\text { no. }\end{array}$ & Range & $\begin{array}{c}\text { Mitotic } \\
\text { index }(\%)\end{array}$ \\
\hline 1 & 4 & 13 & 64 & 45 to 96 & 4.3 \\
2 & $8 *$ & 8 & 60 & 42 to 90 & 0 \\
3 & $10 \dagger$ & 23 & 88 & 41 to 188 & 0 \\
\hline
\end{tabular}

* Removed from the uterus on the 4th day and cultured for 4 days in the medium of Gwatkin (1966) except that the Eagle's medium was modified (Vogt \& Dulbecco, 1963) and supplemented with 10\% rather than $1 \%$ dialysed fetal calf serum.

+ Ovariectomized at noon on the 3rd day of pregnancy and flushed from the uterus 7 days later.

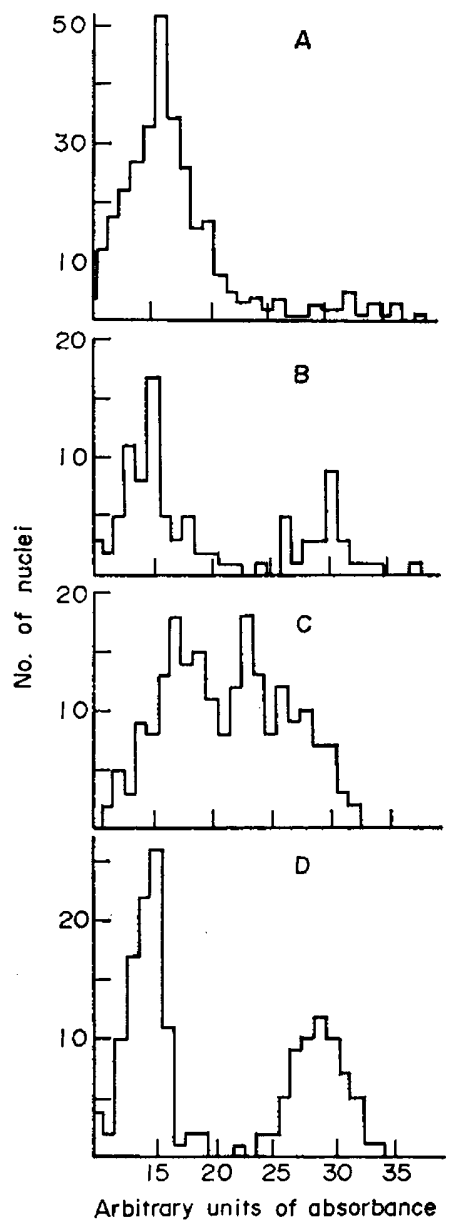

TExT-FIG. 1. Deoxyribonucleic acid content of nuclei of normal blastocysts and of blastocysts in delay. Spreads of (A) delayed in vivo, (B) delayed in vitro or (C) normal mid-4th day blastocysts (see footnotes to Table 1) were prepared, stained with Schiff's reagent and measured for DNA content as described elsewhere (Barlow \& Sherman, 1972). The histogram in (D) illustrates the 2C and 4G DNA classes seen in liver nuclei imprints (where $\mathrm{C}$ is the haploid amount of DNA). The scale on the abscissa represents machine units of absorbance. 
(terminology of Howard \& Pelc, 1953), characteristic of the state of 'quiescent' cells (Baserga, 1968). On the other hand, after 4 days in Gwatkin's medium, blastocyst nuclei are found to contain substantial numbers of $4 \mathrm{C}$, as well as $2 \mathrm{C}$, nuclei with a very small percentage of intermediates (Text-fig. 1B). The nuclei of delayed blastocysts in vitro thus appear to be blocked both in the G1 and G2 phases of the cell cycle. This would be expected if the block were due to cessation of protein synthesis (Baserga, 1968). The histogram of normal 4th day blastocysts is different from both of the delayed blastocyst profiles in that a large number of nuclei contain amounts of DNA intermediate between $2 \mathrm{C}$ and 4C (Text-fig. 1C).

It has been shown that some cells of the 5th day blastocyst, presumably trophoblast, begin to accumulate nuclear DNA (Graham, 1971; Barlow, Owen \& Graham, 1972; Barlow \& Sherman, 1972). The onset of this increase in nuclear DNA content has been shown to be independent of the implantation event (Barlow \& Sherman, 1972). Although, as expected (Barlow et al., 1972), the 4th day blastocysts studied here do not contain any nuclei with DNA contents greater than $4 \mathrm{C}$ (Text-fig. 1C), five of the 315 nuclei in Text-fig. 1A and one of ninety-four nuclei in Text-fig. 1B have absorbances greater than that of the largest value for a $4 \mathrm{C}$ liver nucleus. In a second sample of ovariectomy-delayed blastocysts (not shown here), two of eighty-eight nuclei had DNA contents clearly greater than $4 \mathrm{C}$ (unpublished data). Although further study is necessary, it is possible that 1 to $2 \%$ of delayed blastocyst nuclei in vivo and in vitro have begun to accumulate DNA. This percentage is not far below that found in 5th day blastocysts (Graham, 1971; Barlow et al., 1972; Barlow \& Sherman, 1972), and may be an underestimate because some of the nuclei with $4 \mathrm{C}$ amounts of DNA may be in the Gl phase of the endoreduplication cycle if the increase in DNA content is due to endoreduplication.

Subsequent to his finding that arginine and leucine were required for trophoblast outgrowth in culture, Gwatkin analysed the uterine fluid for the level of these two amino acids (Gwatkin, 1969). He found that they were present in the same amounts during normal pregnancy and in ovariectomy delay (Gwatkin, 1969). He concluded that the mechanisms behind delay in vivo and the prevention of trophoblast outgrowth in vitro were probably not the same (Gwatkin, 1969). The clear difference between the histograms in Text-figs. 1A and $1 \mathrm{~B}$ supports this conclusion.

If cells from ovariectomy-delayed blastocysts were blocked in G1, as Textfig. 1A suggests, then following release from the block in the presence of a labelled DNA precursor, all mitotic figures should be labelled. In a preliminary experiment designed to test this prediction, blastocysts were released from delay on the 10th day p.c. by culture in Eagle's medium supplemented with $10 \%$ fetal calf serum (Gwatkin, 1966) and containing $0.5 \mu \mathrm{Ci} / \mathrm{ml}$ tritiated thymidine. Although labelled nuclei were detected by autoradiography of blastocyst spreads after as little as $1 \mathrm{hr}$ in this medium, surprisingly no mitotic figures were detected even after $26 \mathrm{hr}$ in culture and exposure to Colcemid. Under these circumstances, the finding that as many as $73 \%$ of the blastocyst nuclei were labelled after this time supports the evidence in Text-fig. 1A that the majority of cells had been blocked in Gl or early in S phase. 
This work was carried out in the laboratory of Dr G. F. Graham. We wish to thank him for suggestions and for reading the manuscript. We are grateful to the Medical Research Council and the Medical Research Council of Canada for support. The excellent technical assistance of Miss Z. White is acknowledged.

\section{REFERENCES}

Barlow, P. W., Owen, D. A. J. \& Graham, C. (1972) DNA synthesis in the preimplantation mouse embryo. F. Embryol. exp. Morph. (In press).

Barlow, P. W. \& Sherman, M. I. (1972) The biochemistry of differentiation of mouse trophoblast: studies on polyploidy. F. Embryol. exp. Morph. (In press).

Baserga, R. (1968) Biochemistry of the cell cycle. Cell Tissue Kinet. 1, 167.

Cole, R. J. \& Paul, J. (1965) Properties of cultured and preimplantation mouse and rabbit embryos and cell strains derived from them. In: Preimplantation Stages in Pregnancy, pp. 82-112. Eds. G. E. W. Wolstenholme and M. O'Connor. Little, Brown, Boston.

Graham, C. F. (1971) Virus assisted fusion of embryonic cells. Acta endocr., Copenh., Suppl. 153, 154.

Gwatkin, R. B. L. (1966) Amino acid requirements for attachment and outgrowth of the mouse blastocyst in vitro. 7. Cell Physiol. 68, 335.

GWatkin, R. B. L. (1969) Nutritional requirements for post-blastocyst development in the mouse. Int. F. Fert. 14, 101.

Howard, A. \& PELc, S. R. (1953) Synthesis of deoxyribonucleic acid in normal and irradiated cells in relation to chromosome breakage. Heredity, Suppl. 6, 261.

McLAREN, A. (1968) A study of blastocysts during delay and subsequent implantation in lactating mice. 7. Endocr. 42, 453.

MaLaren, A. (1972) Blastocyst activation. In: The Regulation of Mammalian Reproduction. Eds. S. J. Segal, R. Crozier and P. Corfman. Charles C. Thomas, Springfield. (In press).

Mintz, B. (1964) Formation of genetically mosaic mouse embryos and early development of 'lethal $\left(\mathrm{t}^{12} / \mathrm{t}^{12}\right)$-normal' mosaics. F. exp. Zool. 157, 273.

VoGt, M. \& Dulbecco, R. (1963) Steps in the neoplastic transformation of embryonic cells by polyoma virus. Proc. natn. Acad. Sci. U.S.A. 49, 171. 